\title{
Diversity of Decapod Crustaceans in Lasongko Bay, South- east Sulawesi, Indonesia
}

\author{
Abdul Hamid' \& Yusli Wardiatno $2,3^{*}$ \\ ${ }^{1}$ Department of Aquatic Resources Management, Faculty of Fisheries and Marine Science, Halu Oleo University, Kendari, Indo- \\ nesia \\ ${ }^{2}$ Department of Aquatic Resources Management, Faculty of Fisheries and Marine Sciences, Bogor Agricultural University, Kampus \\ IPB Darmaga, Bogor 16680, West Java, Indonesia \\ ${ }^{3}$ Center for Coastal and Marine Resources Studies, Bogor Agricultural University, Kampus IPB Baranangsiang, Jl. Raya Pajajaran, \\ Bogor 16143, West Java, Indonesia \\ "Corresponding author: email: yusli@ipb.ac.id
}

ABSTRACT

The aim of this study was to reveal the species diversity of Decapod Crustaceans in Lasongko Bay, Southeast Sulawesi, Indonesia. The study was conducted from April 2013 to March 2014. The sample collections were conducted on a monthly basis using gillnets at six stations. The abundance, diversity, and similarity indices of decapod species are presented spatially and temporally. Nineteen families and thirty-eight species were found in the bay, and they were dominated by the brachyuran group. The Shannon-Weiner diversity index, the evenness index, and the Simpson dominance index of the decapods spatially ranged 0.812-0.893, $0.592-0.683$, and $0.215-0.313$, respectively. The species similarity index ranged 0.560 0.831 spatially and $0.363-0.902$ temporally. Decapods with high economic value were also discussed.

KEY WORDS

Abundance; Brachyura; Muna Island; Crustacea; similarity.

Received 03.06.2018; accepted 02.08.2018; printed 30.09.2018; published online 05.10.2018

\section{INTRODUCTION}

The decapod crustaceans, consisting of crabs (Brachyura) and shrimps (Macrura), play important ecological roles (Aswandy, 2008) and have a high economic value in some species. Some species of decapods are high-value resources and become protein sources for human, such as penaeid shrimp, lobsters (Panurilus spp.), mud crabs (Scylla spp.), and blue swimming crabs (Portunus pelagicus Linnaeus, 1758). There are 14,756 different species of decapods in the world (De Grave et al., 2009), and brachyuran groups range from 5,000 to 10,000 species (Chakravarty et al., 2016), of which about
6793 species inhabit marine ecosystems ( $\mathrm{Ng}$ et al., 2008; Kumaralingam et al., 2013).

Indonesian waters have a high diversity of decapod crustaceans, but are still poorly documented (Hutomo \& Moosa, 2005). The decapod crustaceans found in Indonesian marine waters are about 1502 species, comprising 1,400 species of the brachyura group and 102 species of the Stomatopod group (Hutomo \& Moosa, 2005). Researches on decapod crustaceans diversity in Indonesian marine waters have been carried out by Moosa (1980), Moosa \& Aswandy (1994), Widyastuti (2007), Aswandy (2008), Pratiwi (2010, 2012), Pratiwi \& Astuti (2012), Pratiwi \& Widyastuti (2013), Pratiwi \& Wijaya (2013), Anggorowati (2014), Anggraeni et al. 
(2015), Mashar et al. (2014, 2015), Ardika et al. (2015), Wardiatno et al. (2015a, b), and Wardiatno et al. $(2016 a, b)$. The results of several studies have shown that the diversity of decapod species varied across locations and many of the studies still emphasized on the spatial aspect, whereas the diversity of decapod crustaceans was associated with season variability (Andrade et al., 2015). In terms of location, most of research on the biodiversity in Indonesia has been concentrated in the western region.

Lasongko Bay is a small bay located in Central Buton, Southeast Sulawesi, in the eastern part of Indonesia. The bay has been the fishing ground of the blue swimming crab fishery, and many biological aspects of the blue swimming crab in the bay have been reported, i.e., reproductive aspects (Hamid et al., 2015a, b; Hamid et al., 2016a), population dynamic and stock (Hamid \& Wardiatno, 2015; Hamid et al., 2016a, c, d), and fishery management (Hamid et al., 2017). In the blue swimming crab fishery, many of the other Decapod Crustacean species are also caught as bycatch. This study aimed to reveal the diversity of decapod crustacean species spatially and temporally in Lasongko Bay, Southeast Sulawesi, Indonesia.

\section{MATERIAL AND METHODS}

\section{Study area}

The study was conducted in Lasongko Bay, Central Buton, Southeast Sulawesi - Indonesia. The bay is located at the latitude $05^{\circ} 15^{\prime}$ to $05^{\circ} 27^{\prime} \mathrm{S}$ and longitude $122^{\circ} 27^{\prime}$ to $122^{\circ} 33^{\prime} \mathrm{E}$ (Figure 1). Decapods have been collected on six stations situated from the inner to the middle part of the bay. Stations 1 to 5 are situated in the area between lower intertidal and subtidal zone. The seagrass was present in the area between lower intertidal and upper subtidal zone with sandy sediments, while the subtidal zone was a bare sandy area (Hamid et al., 2016a). Stations 1 and 2, situated near the coastline, are influenced by mangrove ecosystems. Station 6 is in the middle of the bay with a sandy clay substrate in the sea bed (Hamid et al., 2016a).

\section{Sampling}

Decapods samplings at each station were done monthly, from April 2013 to March 2014. Sample collections were conducted by gillnets with mesh

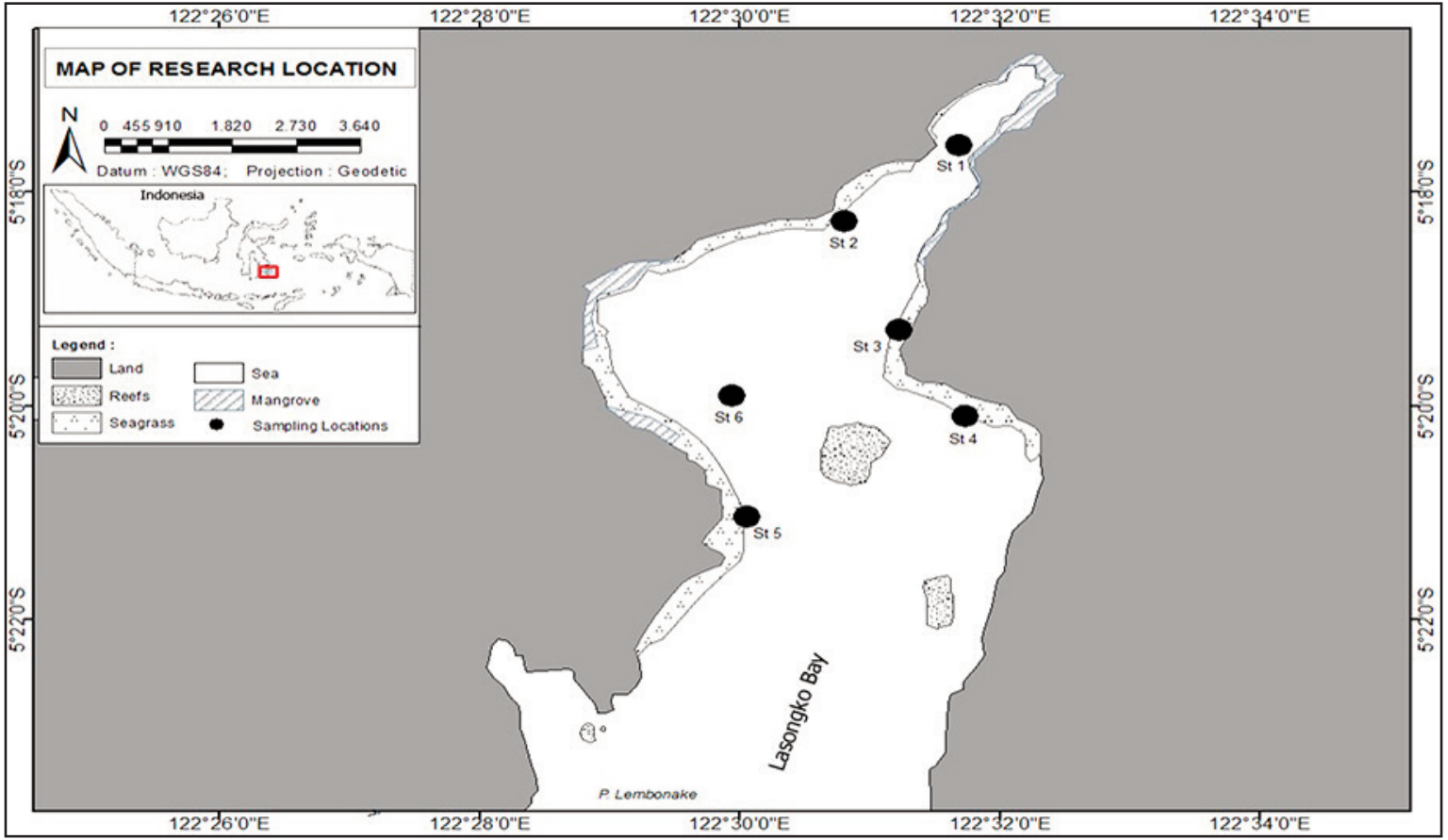

Figure 1. Map showing the location of the study site in Lasongko Bay, Southeast Sulawesi, Indonesia. Sampling sites are indicated by the black dots (adapted from Hamid, 2015). 
sizes of $3.81,6.35$, and $8.89 \mathrm{~cm}$. The gillnet was deployed in the afternoon and hauled in the morning of the next day. The decapods caught on each sampling were identified following $\mathrm{Ng}$ (1998), Chan (1998), Ng et al. (2008), and Khvorov (2012), and counted. Habitat characteristics such as temperature, salinity, dissolved oxygen, $\mathrm{pH}$, turbidity, and total suspended solids were taken from Hamid (2015).

\section{Data analysis}

The data were grouped spatially (station) and temporally (sampling period) for analysis. To evaluate the diversity, three biological indices were used (e.g. Shannon-Wiener index, evenness index, and the Simpson dominance index). The species similarity index between stations was calculated by the Sorensen index (Brower et al., 1990).

\section{RESULTS}

\section{Habitat Conditions}

Habitat characteristics in Lasongko Bay during the study showed variation, but were still within the optimum limit for decapods life. The range of some environmental parameters are as follow: temperature, $23.6-35.6^{\circ} \mathrm{C}$; turbidity, $0.20-6.78 \mathrm{NTU}$; total suspended solid, 19.0-293.0 mg. 1-1; dissolved oxygen, 3.05-7.77 mg. 1-1; salinity, 16.0-35.0 psu; pH, 7.45-8.74 (Hamid, 2015).

\section{Species Composition of Decapods}

The collected decapods found during the study were 2508 individuls, consisting of two groups, the Brachyura group (16 families and 34 species) and the Macrura group ( 3 families and 4 species). All collected decapod crustaceans can be seen in Table 1. Some familes and species have always been found in each station and at each sampling time. These families are Portunidae, Dorippidae, Calappidae, Xanthidae, and Majidae (Figure 2). The species are Portunus pelagicus, Dorippe sinica, Callapa hepatica, Schizophrys aspera, Podothalmus vigil, Charybdis anisodon, Thalamita crenata, T. spinimana, T. sima, and Lophozozymus pictor.

\section{Spatial Diversity}

Decapods abundance at each station ranged from 243 to 730 individuals and the number of species ranged from 16 to 26 species. The highest abundance and species were found at station 1, while the lowest abundance at station 6 and the lowest number of species at station 3 (Table 1). The Shannon-Weiner diversity index ranged from 0.812 to 0.893 . In addition, the evenness and Simpson dominance indices ranged from 0.592 to 0.683 and from 0.215 to 0.313 , respectively. The similarity index of the decapod species between stations ranged from 0.560 to 0.831 . The highest was found between stations 2 and 3, and the lowest between stations 1 and 4 (Table 2).

\section{Temporal Diversity}

According to the sampling period, the number of decapod species found ranged from 10 to 25 species with abundance ranging from 125 to 312 individuals. The highest number of species and abundance were found in March and May, while the lowest in December (Table 3). The ShannonWiener diversity ranged from 0.339 to 1.075 , and the evenness and Simpson dominance indices ranged from 0.362 to 0.847 and from 0.113 to 0.710 , respectively.

\section{Decapoda Species of Economic Value}

The number of decapod species with economic value found in this study were 20 species from the families Penaeidae, Portunidae, Calappidae, Dromiidae, Palinuridae, and Scyllaridae. Among the twenty species, six are categorized as decapods with high economic value: $P$. pelagicus, $P$. versicolor, $P$. monodon, P. merguensis, $S$. serrata, and Thenus orientalis.

\section{DISCUSSION AND CONCLUSIONS}

Portunidae was the dominant family found in Lasongko Bay (Table 1 and Figure 2), and this finding is identical to previous researches (Pratiwi \& Wijaya, 2013; Varadharajan et al., 2013; Kumaralingan et al., 2013; Sruthi et al., 2014; Anggraeni et al., 2015; Fazrul et al., 2015; Pawar et al., 2017). 


\begin{tabular}{|c|c|c|c|c|c|c|c|c|}
\hline \multirow{2}{*}{ No. } & \multirow{2}{*}{ Family } & \multirow{2}{*}{ Species } & \multicolumn{6}{|c|}{ Station } \\
\hline & & & 1 & 2 & 3 & 4 & 5 & 6 \\
\hline \multirow[t]{3}{*}{1.} & Calappidae & Callapa callapa & 1 & 17 & 1 & 9 & & 1 \\
\hline & & C. philargius & & & & & 1 & 1 \\
\hline & & C. hepatica & 8 & 42 & 8 & 18 & 4 & 6 \\
\hline 2. & Dorippidae & Dorippe sinica & 13 & 34 & 29 & 14 & 31 & 33 \\
\hline 3. & Dromiidae & Dromia dormia & & 3 & 4 & 6 & 11 & 2 \\
\hline 4. & Epialtidae & Phalangipus sp. & & & & 1 & 1 & \\
\hline 5. & Grapsidae & Metopograpsus sp. & 1 & 3 & & & & \\
\hline 6. & Inachidae & Compascia retusa & & & & 1 & & \\
\hline 7. & Leucosiidae & Randalia sp. & 1 & & & & 2 & 1 \\
\hline 8. & Majidae & Schizophrys aspera & 19 & 16 & 8 & 3 & 5 & 5 \\
\hline 9. & Matutidae & Ashtoret lunaris & 3 & 2 & 4 & 4 & & 3 \\
\hline 10. & Menippidae & Myomenippe hardwickii & 7 & 15 & & & 3 & 1 \\
\hline 11. & Palinuridae & Panulirus versicolor & 2 & & & & & \\
\hline 12. & Parthenopidae & Rhinolambrus pelagicus & 1 & 7 & & 1 & 1 & 5 \\
\hline 13. & Penaeidae & $\begin{array}{l}\text { Penaus. monodon } \\
P \text { merouensis }\end{array}$ & $\begin{array}{c}9 \\
16\end{array}$ & & & & & \\
\hline \multirow[t]{3}{*}{14.} & Pilumnidae & Pilumnus sp. & & 10 & & 2 & & 1 \\
\hline & & Heteropanope indica & & & & 1 & & 3 \\
\hline & & Nano pilumnus & & 3 & & 2 & & \\
\hline \multirow[t]{12}{*}{15.} & Portunidae & Portunus pelagicus & 265 & 346 & 132 & 148 & 136 & 115 \\
\hline & & P. granulatus & & & & 1 & 2 & 4 \\
\hline & & Podothalmus vigil & 40 & 25 & 7 & 9 & 16 & 16 \\
\hline & & Charybdis affinis & 88 & 7 & 2 & 7 & & 6 \\
\hline & & C. anisodon & 180 & 39 & 4 & 10 & 10 & 7 \\
\hline & & C. natator & 31 & 6 & 21 & 2 & 4 & \\
\hline & & Charybdis $s p$. & 1 & & & & & \\
\hline & & Thalamita crenata & 26 & 37 & 3 & 2 & 4 & 2 \\
\hline & & T. sima & 4 & 35 & 17 & 3 & 1 & 5 \\
\hline & & T. spinimana & 4 & 33 & 47 & 6 & 12 & 8 \\
\hline & & Thallamita sp. & & 2 & 1 & 1 & 1 & 2 \\
\hline & & Scylla serrata & 2 & & & & & \\
\hline 16. & Sesarmidae & Neopisesarma sp. & 2 & & & & & \\
\hline 17. & Scyllaridae & Thenus orientalis & & & & 4 & 1 & \\
\hline 18. & Varunidae & Hemigrapsus sp. & & 7 & & & & \\
\hline \multirow[t]{4}{*}{19.} & Xanthidae & Lophozozymus pictor & 4 & 11 & 9 & 9 & 22 & 9 \\
\hline & & Atergatis integerrimus & 1 & & & & & 7 \\
\hline & & Leptodius sanguineus & 1 & & & & & \\
\hline & & Etisus $s p$. & & 2 & & & 4 & \\
\hline \multicolumn{3}{|c|}{ Number of species } & 26 & 23 & 16 & 24 & 21 & 23 \\
\hline \multicolumn{3}{|c|}{ Abundance } & 730 & 702 & 297 & 264 & 272 & 243 \\
\hline \multicolumn{3}{|c|}{$\begin{array}{l}\text { Shannon-Wiener index } \\
\text { Evenness index }\end{array}$} & 0.868 & 0.898 & 0.822 & 0.817 & 0.812 & 0.893 \\
\hline \multirow{2}{*}{\multicolumn{3}{|c|}{$\begin{array}{l}\text { Evenness index } \\
\text { Simpson Dominance index }\end{array}$}} & 0.613 & 0.651 & 0.683 & 0.592 & 0.614 & 0.656 \\
\hline & & & 0.215 & 0.260 & 0.235 & 0.313 & 0.254 & 0.246 \\
\hline
\end{tabular}

Table 1. Decapod family and species found in Lasongko Bay, Southeast Sulawesi, Indonesia.

\begin{tabular}{|ccccccc|}
\hline \multirow{2}{*}{ Station } & \multicolumn{7}{c|}{ Similarity index } & at each station \\
\cline { 2 - 7 } & 1 & 2 & 3 & 4 & 5 & 6 \\
\hline 1 & - & 0.653 & 0.619 & 0.56 & 0.596 & 0.694 \\
2 & & - & 0.831 & 0.723 & 0.727 & 0.783 \\
3 & & & - & 0.800 & 0.703 & 0.769 \\
4 & & & & - & 0.756 & 0.809 \\
5 & & & & & - & 0.773 \\
6 & & & & & & - \\
\hline
\end{tabular}

Table 2. Matrix of Sorensen similarity index of Decapods among stations in Lasongko Bay, SE Sulawesi, Indonesia. 


\begin{tabular}{|lccccc|}
\hline \multirow{2}{*}{$\begin{array}{c}\text { Sampling } \\
\text { Time }\end{array}$} & No. of species & $\begin{array}{c}\text { Abundance } \\
\text { (individual) }\end{array}$ & $\begin{array}{c}\text { Shannon } \\
\text {-Wiener }\end{array}$ & Evenness & $\begin{array}{c}\text { Simpson } \\
\text { Dominance }\end{array}$ \\
\hline April 13 & 11 & 138 & 0.339 & 0.362 & 0.710 \\
May 13 & 20 & 312 & 0.736 & 0.568 & 0.372 \\
June 13 & 21 & 233 & 0.892 & 0.707 & 0.238 \\
July13 & 18 & 178 & 0.830 & 0.693 & 0.263 \\
Augustus 13 & 20 & 160 & 0.932 & 0.743 & 0.210 \\
September & 19 & 129 & 0.944 & 0.771 & 0.178 \\
October 13 & 19 & 151 & 0.994 & 0.785 & 0.137 \\
November 13 & 19 & 217 & 1.058 & 0.847 & 0.113 \\
December 13 & 10 & 125 & 0.541 & 0.558 & 0.435 \\
January 14 & 24 & 307 & 0.946 & 0.699 & 0.198 \\
February 14 & 22 & 254 & 1.075 & 0.806 & 0.143 \\
March 14 & 25 & 218 & 1.071 & 0.807 & 0.129 \\
\hline
\end{tabular}

Table 3. The number of species, abundance, and biological indices of Decapod Crustaceans based on sampling time in Lasongko Bay, Southeast Sulawesi, Indonesia.

\begin{tabular}{|lccl|}
\hline Location & $\begin{array}{c}\text { No. of } \\
\text { species }\end{array}$ & $\begin{array}{c}\text { Diversity } \\
\text { index }\left(\mathrm{H}^{\prime}\right)\end{array}$ & Sources \\
\hline Kawhia, New Zealand & 29 & - & Morley et al., 1997 \\
Minden and Roe Reefs, West & 46 & - & Richards et al., 2016 \\
Australia & 22 & $<0.5$ & Ndoro et al., 2014 \\
Malindi-Ungwana Bay, Kenya & 22 & - & Lui et al., 2007 \\
Hong Kong waters & $34^{\mathrm{a}}$ & & Sakthivel \& Fernando, 2012 \\
Mudasal Odai coast, India & 47 & $2.94-3.38$ & Kumaralingam et al., 2013 \\
North Andaman sea, India & 47 & - & Varadharajan et al., 2013 \\
Puducherry coast, India & $40^{\mathrm{a}}$ & - & Sruthi et al., 2014 \\
Kanyakumari coast, India & 55 & $3.13-5.53$ & Pillai et al., 2014 \\
Tamil Nadu coast, India & $31^{\mathrm{a}}$ & - & Pawar. 2017 \\
Uran coast, India & $29^{\mathrm{a}}$ & - & Dev Roy et al., 2017 \\
Odisha coast, India & $41^{\mathrm{a}}$ & - & Huang et al., 2011 \\
Shantou Bay, China & 28 & - & Fazrul et al., 2015 \\
Pattani coast, Thailand & 17 & - & Kunsook \& Dumrongrojwatthana, 2017 \\
Kung Krabaen Bay, Thailand & & & \\
\hline Indonesia : & 50 & - & Moosa \& Aswandy, 1994 \\
\hline South Lombok, seagrass bed & 39 & $0.65-0.98$ & Widyastuti, 2007 \\
Anambas Islands & 57 & $0.66-3.00^{*}$ & Pratiwi, 2010 \\
Lampung Bay, seagrass bed & 15 & $1.121-3.744^{*}$ & Pratiwi \& Astuti, 2012 \\
Kendari Waters, open waters & 31 & $0.39-2.10^{*}$ & Pratiwi \& Widyastuti 2013 \\
Lampung Bay, mangroves & 59 & $0.97-3.74^{*}$ & Pratiwi \& Wijaya, 2013 \\
Matasiri Islands & 85 & - & Anggorowati, 2014 \\
West Lombok & $31^{\mathrm{a}}$ & - & Anggraeni et al., 2015 \\
Tikus Island, Seribu Islands & $19^{\mathrm{a}}$ & $0.673-1.954^{*}$ & Widyastuti, 2016 \\
Lingga, Riau Islands, mangroves & 38 & $0.377-1.129$ & This study \\
Lasongko Bay & & \\
\hline Note: * log a: brachyura only & $-:$ no data & & \\
\hline
\end{tabular}

Table 4. Number of species and Shannon-Wiener (H') index of Decapods community in some waters of the world. 
The number of species and abundance of decapods in this study showed variations both spatially and temporally. It might be due to the spatial-temporal variation in habitat conditions. In terms of abundance, decapods found in this study were more than the ones found in other Indonesia waters (Pratiwi, 2010; Pratiwi \& Wijaya, 2013; Anggorowari, 2014; Anggraeni et al., 2015). The number of decapod species found in the waters of Lasongko Bay was still within the range of decapod species found in other waters of the world and Indonesia, ranging from 15 to 85 species (Table 4).

The species number of Brachyura group found in this study were higher than that found by Fahzul et al. (2015), Dev Roy et al. (2017), Kunsook \& Dumrongrojwatthana (2017), Pawar et al. (2017), and were lower than that found by Huang et al. (2011), Sruthi et al. (2014), as well as those found by Sakthivel \& Fernando (2012). The number of species and abundance of decapods were influenced by the substrate type and seagrass density (Aswandy, 2008; Huang et al., 2011; Anggorowati, 2014; Andrade et al., 2015; Hamid, 2015), as well as temperature, salinity, oxygen, turbidity, and water depth (Lui et al., 2007; Ndoro et al., 2014; Andrade et al., 2015; Hamid, 2015; Kunsook \& Dumrongrojwatthana, 2017).

Based on the sampling time, decapods diversity in Lasongko bay was generally low, except in November, February, and March, indicating ecological stress, probably due to fishing intensity. The diversity value of decapods in this study was lower compared to previous studies (Widyastuti, 2007, 2016; Pratiwi, 2010; Pratiwi \& Astuti, 2012; Kumaralingam et al., 2013; Pratiwi \& Wijaya, 2013; Pratiwi \& Widyastuti, 2013a; Pillai et al., 2014; see Table 4). The evenness index of decapods in Lasongko Bay was moderate, indicating that the spatially-temporally distribution of the species tends to spread evenly. It is also supported by the low spatially-temporally dominance index values (Tables 1 and 2). The values of the evenness index and Simpson dominance indicess were still comparable with previous studies (Pratiwi, 2010; Pratiwi \& Astuti, 2012; Pratiwi \& Wijaya, 2013; Anggorowati, 2014), which ranged from 0.360 to 0.970 and from 0.070 to 0.620 , respectively.

The species similarities found in this study tended to vary. Anggorowati (2015) suggests that a species similarity more than 0.61 is high. The species similarity of decapods in this study was higher than the one reported by Kumaralingam et al. (2013), Anggorowati (2014), and Pillai et al. (2014). At stations 2 and 3, 23 species and 16 species were found. These two stations have the highest species similarity of decapods, because all the decapod species found in station 3 are also found in station 2 . The two stations are relatively similar to the seagrass bed conditions, i.e. Thalassia hemprichii dominated, but the substrate type on the subtidal were different, i.e., on the stations 2 , substrate type was sand, while stations 3 has a different substrate type (clay sand) (Hamid 2015; Hamid et al., 2016a).

The species similarity of the decapods between stations 1 and 4 was the lowest. In the two stations, the decapods found belonged to 26 and 24 species, respectively. Of these, only 14 species were found on both stations (Table 2). This may be caused by differences in environmental conditions in both stations. Station 1 is located in the inner part of the bay, influenced by a dense mangrove ecosystem and a low density seagrass bed. The substrate was muddy, its salinity was lower and the water was more turbid compared to other stations (Hamid, 2015; Hamid et al., 2016a). In contrast, station 4 is relatively open, the seagrass bed was large and dense with a sandy substrate (Hamid et al., 2016a). However, there is an interesting thing about station 1. The species of Panulirus versicolor, Penaeus monodon, Penaeus merguensis, Charybdis sp., Scylla serrata, Neopisesarma sp., Atergatis integerrimus, and Leptodius sanguineus were found only in station 1 and not in any other stations.

The number of the species of economic valuable in this study is the same as found by Lui et al. (2007), and more than the one reported by Kunsook \& Dumrongrojwatthana (2017), while the number of species with high economic value were less than Huang et al. (2011), Pratiwi \& Astuti (2012), and Pratiwi \& Wijaya (2013). Portunus pelagicus is one of the most valuable species, and has been a target for fishing in Lasongko Bay since the 1970s until now (Hamid et al., 2016d). The other 37 decapod species are bycatch of the blue swimming crab fishery in Lasongko Bay using gillnets. The gillnet was considered to be a selective fishing gear compared to trap for blue swimming crab fisheries (Fazrul et al., 2015; Kunsook \& Dumrongrojwatthana, 2017), this finding however showed that there were still some other decapod species caught as bycatch. The 


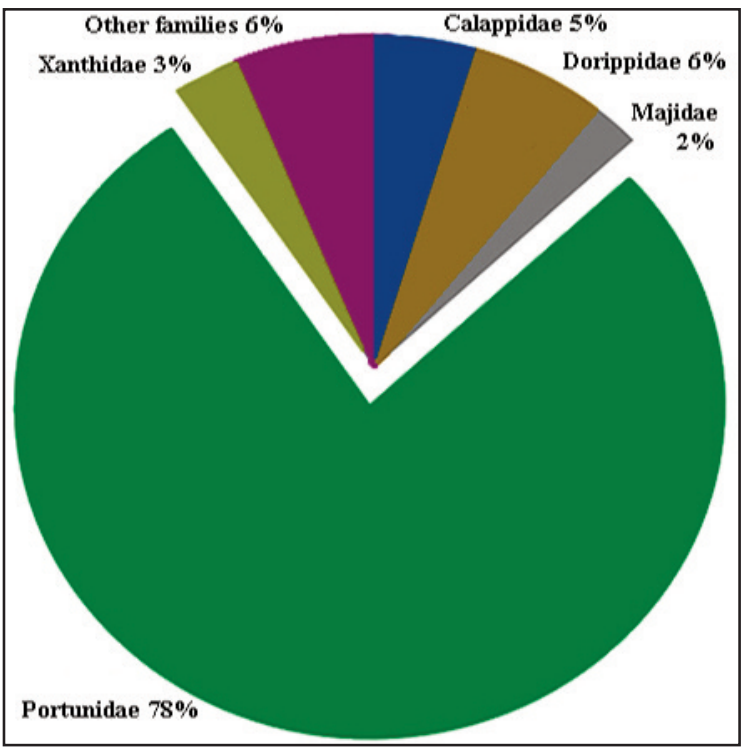

Figure 2. Family composition of the dominant Decapods based on abundance in Lasongko Bay, SE Sulawesi, Indonesia.

list of bycatches would be longer if fishes and molluscs were to be included.

\section{ACKNOWLEDGEMENTS}

Kaharudin and La Mpiri are thanked for their assistance during sampling in the field. The research is part of a research collaboration between Crustacean Research Group of Bogor Agricultural University and Halu Oleo University.

\section{REFERENCES}

Anggorowati D.A., 2014. Community structure of crustacean fauna at the intertidal zone of west Lombok. Jurnal Zoologi Indonesia, 23: 92-100.

Andrade L.S., Frameschi I.F., Costa R.C., Castilho A.L. \& Fransozo A., 2015. The assemblage composition and structure of swimming crabs (Portunoidea) in continental shelf waters of southeastern Brazil. Continental Shelf Research, 94: 8-16.

Anggraeni P., Elfidasari D. \& Pratiwi R., 2015. Brachyuran crab distribution in Tikus Island, Pari Island group, Seribu Islands. Prosiding Seminar Nasional Masyarakat Biodiversitas Indonesia, 1: 213-221.

Ardika P.U., Farajallah A. \& Wardiatno Y., 2015. First record of Hippa adactyla (Fabricius, 1787; Crus- tacea, Anomura, Hippidae) from Indonesian waters. Tropical Life Sciences Research, 26: 105-110.

Aswandy I., 2008. Crustacean community structure in Cisadane estuaria and its surrounding area. Oseanologi dan Limnologi di Indonesia, 34: 67-81.

Brower J., Jerrold H.Z. \& Ende N.V.E., 1990. Field and laboratory methods for general ecology. Third edition. Wm. C. Brown Publishers. Dubuque. Iowa, USA. 220 pp.

Chakravarty M.S., Ganesh P.R.C., Amarnath D., Sudha B.S. \& Vivek V., 2016. Diversity of crabs in Tekkali creek, Srikakulam district, Andhra Pradesh. International Journal of Fisheries and Aquatic Studies, 4: 414-418.

Chan T.Y., 1998. Shrimps and prawns. In: Carpenter K.E. \& Niem V.H. (Eds), FAO Species Identification Guide for Fishery Purposes. The living Marine Resources of the Western Central Pacific. 1998. Volume 2. FAO, Rome, pp. 851-971.

De Grave S., Pentcheff N.D., Ahyong S.T., Tin-Yam C., Crandall K.A., Dworschak P.C., Felder D.L., Feldmann R.M., Fransen C.J.M., Goulding L.Y.D., Lemaitre R., Low M.E.Y., Martin J.W., Ng P.K.L., Schweitzer C.E., Tan S.H., Tshudy D. \& Wetzer R., 2009. A classification of living and fossil genera of decapod crustaceans. Raffles Bulletin of Zoology, 21: 1-109.

Dev Roy M.K., Rath S. \& Nandi N.C., 2017. A note on portunid crabs of Odisha Coast, India. Oceanography and Fisheries Open access Journal, 1: 1-3.

Fazrul H., Hajisamae S., Ikhwanuddin M. \& Pradit S., 2015. Assessing impact of crab gill net fishery to bycatch population in the Lower Gulf of Thailand. Turkish Journal of Fisheries and Aquatic Sciences, 15: 761-771.

Hamid A., 2015. Habitat, reproductive biology and population dynamic of the blue swimming crab (Portunus pelagicus Linnaeus, 1758) as a basic of its management at Lasongko Bay, Southeast Sulawesi. PhD Dissertation. Graduate School of Bogor Agricultural University, Bogor, 160 pp.

Hamid A. \& Wardiatno Y., 2015. Population dynamics of the blue swimming crab (Portunus pelagicus Linnaeus, 1758) in Lasongko Bay, Central Buton, Indonesia. AACL Bioflux, 8: 729-739.

Hamid A., Wardiatno Y., Lumbanbatu D.T.F. \& Riany E., 2015a. Fecundity and gonad maturity stages of ovigerous female blue swimming crab (Portunus pelagicus) in Lasongko Bay, Southeast Sulawesi. Bawal, 7: 43-50.

Hamid A., Wardiatno Y., Lumbanbatu D T F. \& Riany E., 2015b. Changes in proximate and fatty acids of the eggs during embryo development in the blue swimming crab, Portunus pelagicus (Linnaeus, 1758) at Lasongko bay, Southeast Sulawesi, Indonesia. Indian Journal of Science and Technology, 8: 501-509. 
Hamid A., Wardiatno Y., Lumbanbatu D.T.F. \& Riany E., 2016a. Distribution, body size, and eggs of ovigerous swimming crab (Portunus pelagicus Linnaeus, 1758) at various habitats in Lasongko Bay, Central Buton, Indonesia. International Journal of Aquatic Biology, 4: $115-124$

Hamid A., Lumbanbatu D.T.F., Riany E. \& Wardiatno Y. 2016b. Reproductive biology of blue swimming crab (Portunus pelagicus Linnaeus, 1758) in Lasongko Bay, Southeast Sulawesi-Indonesia. AACL Bioflux, 9: 1053-1066.

Hamid A., Wardiatno Y., Lumbanbatu D.T.F. \& Riany E., 2016c. Distribution of Spatial-Temporal Size and gonad maturity stages based of blue swimming crab (Portunus pelagicus Linnaeus 1758) in Lasongko Bay, Central Buton, Southeast Sulawesi. Omni Akuatika, 12: 77-91.

Hamid A., Wardiatno Y., Lumbanbatu D.T.F. \& Riany E., 2016d. Stock status and fisheries exploitation of blue swimming crab Portunus pelagicus (Linnaeus, 1758) in Lasongko Bay, Central Buton, Indonesia. Asian Fisheries Science, 29: 206-219.

Hamid A., Wardiatno Y., Lumbanbatu D.T.F. \& Riany E., 2017. Sustainable management of blue swimming crab (Portunus pelagicus) based of bioecology aspects in Lasongko Bay, Southeast Sulawesi. Jurnal Kebijakan Perikanan Indonesia, 9: 41-50.

Huang J.R., Brown C.L. \& Yang T.B., 2011. Spatio-temporal patterns of crab fisheries in the main bays of Guangdong Province, China. Iranian Journal of Fisheries Science, 10: 425-436.

Hutomo M. \& Moosa M.K., 2005. Indonesian marine and coastal biodiversity: present status. Indian Journal of Marine Science, 34(1): 88-97.

Khvorov S., 2012. Crabs of Sultanate of Oman. Marine Science Fisheries Centre, Ministry of Agriculture and Fisheries Wealth. Muscat, Oman. 60 pp.

Kumaralingam S., Sivaperuman C. \& Raghunathan C., 2013. Diversity and community structure of brachyuran crabs in North Andaman, In: Venkataraman K., Sivaperuman C. \& Raghunathan C. (Eds.), Ecology and conservation Springer-Verlag Berling Heidelberg, pp.171-182.

Kunsook C. \& Dumrongrojwatthana P., 2017. Species diversity and abundance of marine crabs (Portunidae: Decapoda) from collapsible crab trap fishery at Kung Krabaen Bay, Chanthaburi Province, Thailand. Tropical Life Sciences Research, 28: 45-67.

Lui K.K.Y., Ng J.S.S. \& Leung K.M.Y., 2007. Spatiotemporal variations in the diversity and abundance of commercially important Decapoda and Stomatopoda in subtropical Hong Kong waters. Estuarine, Coastal and Shelf Science, 72: 635-647.

Mashar A., Wardiatno Y., Boer M., Butet N.A. \& Farajallah A., 2014. The diversity and abundance of sand crabs in south coast of Central Java. Ilmu Kelautan: Indonesian Journal of Marine Sciences, 19: 226-232.

Mashar A., Wardiatno Y., Boer M., Butet N.A., Farajallah A. \& Ardika P.U., 2015. First record of Albunea symmysta (Crustacea: Decapoda: Albuneidae) from Sumatra and Java, Indonesia. AACL Bioflux, 8: 611-615.

Moosa M.K., 1980. Some notes about the crab from Jakarta Bay and Seribu islands. In: Burhanuddin, Moosa M.K. \& Razak H. (Eds), Marine biological resources: overview some research results Pelita II. 1980. National Institute of ceanography, Indonesian Institute of Sciences. Jakarta. pp. 42-51.

Moosa M.K. \& Aswandy I., 1994. Crustaceans of seagrass beds in the waters of South Lombok. In: Kiswara W., Moosa M.K. \& Hutomo M. (Eds), Biological community structure of seagrass on the southern coast of Lombok and environmental conditions. 1994. Research Center for Oceanography, Indonesian Institute of Sciences. Jakarta. pp. 42-51.

Ndoro C.K., Kaunda-Arara B., Munga C.N. \& Renison R., 2014. Influence of seasonality and bathymetry on decapod crustacean community structure in MalindiUngwana Bay, Kenya. Western Indian Ocean Journal of Marine Science, 13: 31-46.

Ng P.K.L., 1998. Crabs. In: Carpenter K E. \& Niem V H. (Eds). FAO Species Identification Guide for Fishery Purposes. The living Marine Resources of the Western Central Pacific. 1998. Volume 2. FAO, Rome. pp.1046-1155.

Ng P.K.L., Guinot D. \& Davie P.J.F., 2008. Systema brachyurorum: part I. An annotated checklist of extant brachyuran crabs of the world. The Raffles Bulletin of Zoology, 17: 1-286.

Pawar P.R., 2017. Biodiversity of brachyuran crabs (Crustacea: Decapoda) from Uran, Navi Mumbai, west coast of India. Advances in Environmental Biology, 11: 103-112.

Pillai S.L., Kizhakudan S.J., Radhakrishnan E.V. \& Thirumilu P., 2014. Crustacean bycatch from trawl fishery along north Tamil Nadu coast. Indian Journal of Fisheries, 61: 7-13.

Pratiwi R., 2010. Crustaceans association in seagrass ecosystems Lampung Bay waters. Ilmu Kelautan: Indonesian Journal of Marine Sciences, 15: 66-76.

Pratiwi R., 2012. Species and pattern of distribution of crustaceans fauna in seagrass Pulau Tikus island, Seribu islands. Oseanologi dan Limnologi di Indonesia, 38: 43-55.

Pratiwi R. \& Astuti O., 2012. Biodiversity of crustacean (Decapod, Brachyura, Macrura) from Kendari waters expedition 2011. Ilmu Kelautan: Indonesian Journal of Marine Sciences, 17: 8-14.

Pratiwi R. \& Widyastuti E., 2013. Distributional patterns and zonation of crustaceans mangrove in Lampung Bay. Zoo Indonesia, 22: 11-21. 
Pratiwi R. \& Wijaya N I., 2013. The community diversity of crustacean in Matasiri Islands, South Kalimantan. Berita Biologi, 12: 127-140.

Richards Z., Kirkendale L., Moore G., Hosie A., Huisman J., Bryce M., Marsh L., Bryce C., Hara A., Wilson N., Morrison S., Gomez O., Ritchie J., Whisson C., Allen M., Betterridge L., Wood C., Salotti M.H., Hansen G., Slack-Smith S. \& Fromont J., 2016. Marine biodiversity in temperate Western Australia: Multi-taxon surveys of Minden and Roe Reefs. Diversity, 8: 1-25.
Sakthivel K. \& Fernando A., 2012. Brachyuran crabs diversity in Mudasal Odai and Nagapattinam coast of Southeast India. Arthropods, 1: 136-143.

Sruthi A., Nansimole A., Devi G.T.V. \& Radhakrishnan T., 2014. Diversity of brachyuran crabs of Kanyakumari area, South West Coasts of India. International Journal of Scientific Research, 3: 126-128.

Varadharajan D., Soundarapandian P. \& Pushparajan N., 2013. The global science of crab biodiversity from Puducherry coast, Southeast coast of India. Arthropods, 2: 26-35. 
